\title{
Chapter 24 \\ The Implicit Normative Assumptions of Social Innovation Research: Embracing the Dark Side
}

\author{
Ola Segnestam Larsson and Taco Brandsen
}

\subsection{Introduction}

Social innovation as a concept has moved into the political limelight of many welfare societies in Europe. It has become one of the key buzzwords, beloved by policymakers and practitioners across the world (Borins 2001; Eshima et al. 2001) to a degree where the concept could even be labelled as "policy chic". There are many reasons why social innovation is heralded as a solution, particularly in relation to societal changes in Europe related to welfare programmes that can no longer deal with an increase in social problems. The positive features attributed to the concept are supposed to counterbalance the further slimming down of welfare benefits and services (Evers et al. 2014). Indeed, normative features combined with underlying societal changes provide social innovation with an appeal that seems hard to resist. It combines a determination to reform and improve welfare services in the social arena with a sense of state-of-the-art entrepreneurial and organisational practice. Who could object to such a compelling approach?

Yet, the normative assumptions tend to obscure the dark sides of the phenomenon such as failure, political conflict and oppression. Rather than accepting social innovation at face value, this chapter explores its less palatable side. We believe that the generally optimistic tone in social innovation debates mask a set of problems, both in the concept and in practice, which we will illustrate with the research results from the Welfare Innovations at the Local Level in Favour of Cohesion (WILCO) project. One of the aims of this project was to identify lessons for social policies and ultimately improve social cohesion. Such an optimistic approach should not, how-

\footnotetext{
O. S. Larsson ( $\square)$

Ersta Sköndal University College, 10061 Stockholm, P.O. Box 11189, Stockholm, Sweden e-mail: Ola.Segnestam-Larsson@esh.se

T. Brandsen

Department of Political Science \& Public Administration, Institute of Management Research, Radboud University Nijmegen, PO Box 9108, 6500 HK Nijmegen, The Netherlands e-mail: t.brandsen@fm.ru.nl 
ever, prevent us from discussing the more disturbing elements of social innovation that researchers have identified throughout the project.

As argued in the opening chapter of this publication, as well as in other publications emanating from the WILCO research project (e.g. Evers et al. 2014), the vast majority of the literature on innovation does not use the term social innovation. The small stream of research that does is largely unconnected to the rest. In other words, when we refer to social innovation research, it must always be kept in mind that we are referring to a specific subset and not necessarily the one that is academically best known or most influential.

Literature and policies that do conceptualize, define and use the term social innovation, however, usually frame the concept in a highly positive fashion (e.g. Bureau of European Policy Advisers (BEPA) 2010; Mulgan 2006). Social innovations stand for "improvement" (Phillis 2008) and are linked to a better answer to basic needs as well as more satisfying social relations (Moulaert 2010). There is even talk of a "social innovation movement", though there is no convincing evidence to suggest that there is more social innovation now than 50 or a 100 years ago, nor that it is part of a coherent movement. It appears to be ideology more than a serious assessment. Moreover, this optimistic strand of literature tends to ignore a number of existing and more critical conceptions of social innovations.

This chapter will discuss general criticism of this optimistic approach, highlighting the dark side of social innovation concept and practice, referring to the implicit influence of market and government models, the denial of politics and inflated expectations of diffusion.

Although we will use material from the WILCO project to underpin the argument, we will maintain self-criticism (up to a point). As a project working within specific debates and within specific funding conditions, it too was influenced by some of the more rosy assumptions in the debate. The role of the constructively critical insider is necessarily an ambiguous one. We will try to indicate to what extent we too have been influenced by normative assumptions, to what extent we have managed to avoid them and why.

\subsection{The Influence of Market and Government Models}

Social innovation - though presented as an alternative to markets - is often infused with conceptual baggage from markets and government.

This is most evident in the emphasis on scaling and systemic change. According to this perspective, innovations must grow and be "rolled out". Adaptations of the innovation cycle of social innovations show this as the logical final step for a mature innovation. As we already argued in the earlier chapter, evidence from the WILCO project challenges the idea of scaling in various ways. An overall conclusion is that the life cycles of social innovations, including processes of emergence, stabilization and scaling up, were very conditional and not available at the press of a button. 
Furthermore, most social innovations studied in the WILCO project were not scaled. In addition, it seemed as if most social innovators were far from interested in scaling up their social innovations. One case study of employment social innovation in Zagreb can serve as a first example, as difficulties for scaling up of the project were explicitly discussed (Bezovan et al. 2014a). Main challenges included difficult working conditions of overburdened social workers, lack of financial resources to support clients and too high expectations regarding employment. Similar conclusions were found in the case of employment-based projects in Birmingham as they were intended to be time-limited pilot projects and were small in scale, which meant the opportunity for scaling up was always going to be limited (see Chap. 21 in this book). In fact, our research revealed that many innovations died when their funding ended.

A cyclical perspective implies that innovations that are not scaled are failed innovations, or at best unrealised potential - they get stuck somewhere down the cycle. But this cyclical perspective is adopted from a business context, and as such it carries implicit normative assumptions. It is, paradoxically, a perspective that is similar to one of government: Solutions to problems are to be expanded through bureaucratic, standardised procedures, with an emphasis on equal access and treatment. This underlines that the major distinction in society must not always be between market and state but could also be between universal and contextualised perspectives (Scott 1998). The universal perspectives of market and state deny alternative conceptions of systemic change that rely less on big breakthroughs and more on incremental groundswell delivery (Osborne 1998; Garcia and Calantone 2002). The former perspectives also consistently undervalue the role of alternative providers, such as voluntary organisations and informal initiatives, as they tend to produce the types of locally embedded social innovations that remain under the radar.

Also, the conceptual lens implicit in such perspectives tends to be based on products rather than service processes. Various researchers identified how innovations in services are not only profoundly different from products in terms of the degree of tangibility, separability, perishability and co-production (Sundbo 1997; Drejer 2004; Pestoff and Brandsen 2006; Normann 2007; Osborne 2013). Between market and government, they need an open system orientation that acknowledges the importance, for example, of organisational and institutional environments (Tether 2003). Yet, these perspectives are notable by their absence in the discussion of social innovations in welfare services.

\subsection{The Denial of Politics}

Mainstream literature and policies are strongly in favour of social innovation (or any type of innovation, for that matter), preferably so-called "disruptive" ones. Contained within this conceptualization of social innovation seems to be the normative assumption that any particular innovation must be a good thing, not the least as a result of the emphasis of social in social innovations (Membretti 2007; Meeuwisse 
2008; Miller and Rose 2008). Opposition — often described in terms of barriers - is often regarded as reactionary and somehow in conflict with public interest (compare with Phillis 2008; Murray et al. 2010).

Of course, social innovation as a process may encourage the improvement of welfare services and society more generally, but that does not mean that any specific innovation is necessarily positive. For a start, it downplays the risks involved in any innovative process and the challenges this poses for support and management (Joerges and Nowotny 2003). Risks are an essential part of innovation, but that implies that social innovations often fail (like start-up businesses), which may have all sorts of negative effects. In one Dutch case we examined, the failure of a neighbourhood watch initiative soured relations within the community (Fledderus et al. 2014). Although policy experiments are applauded, these are generally seen as chances for success rather than as opportunities for learning from failure (Borins 2001).

More fundamentally, the normative endorsement of innovation ignores the fact that those who resist it may have a point. Social innovations concern changes in social relations, which means that there are also people who lose by it. Are they simply reactionary forces that need to be overcome? It is not that easy. The interpretation of social innovations is not inherent to the nature of the innovation, and there are often different ways to "read" them. As noted in Chap. 9, "they acquire different senses, depending on the position given to them in the discursive context. This is testament to the open and risky nature of innovations". Indeed, in diffusing innovations, a certain level of ambiguity is often essential to success, because they may have to be reinterpreted and contextualised within a different political discourse. Whether one is for or against them is essentially a question of how one relates to the different discourses.

This points to a disturbing element in discussions on social innovation, which is the tendency to downplay the political context and conflicts of social innovations in welfare services (Pettigrew 1973; Hill and Hupe 2009). As discussed in the introduction to this volume and this chapter, the mainstream literature argues that social innovations to a large degree are not the property of specific social and political orientations. Thus, social innovations stem from the necessity to improve existing welfare services and to devise better solutions (Harris and Aldbury 2009). In other words, social innovations could be considered a normative good (Membretti 2007; Meeuwisse 2008). However, social innovations' values, actions and outcomes will always be contested issues, as discussed earlier. Not only are they prone to the inherent party political nature of welfare policy processes, they are also subject to internal political processes of welfare service organisations and the need of managers to demonstrate their effectiveness in a field of allegedly contested outcomes (Feller 1981).

Social innovations can also be linked with a diversity of political goals. They might take different meanings over time, depending on the wider political concept and institutional system wherein they become embedded (see e.g. Osborne and Brown 2011). In fact, the concept of social innovation was kept in high esteem when linked to the political context in some of the cities included in the project. This was especially the case in dispersed as compared to unified policy environments. One example was Pamplona in Spain (Hendrickson 2014). Although the concept of 
social innovation was not an explicit priority in this city, it was met with sympathy even when it challenged dominant views in the political sphere. The concept was linked to actions of limited scope as offshoots of mainstream programmes, as a way to expand social action without expanding or containing direct public provision. Another example was the city of Malmö in Sweden (Carrigan and Nordfeldt 2014). Innovation was made a key discursive concept in the policy arena around local welfare in Malmö. Political actors considered the concept a cross-political one and used it in the hope of attracting people and organisations from various ideological backgrounds. In both these cities, the concept of social innovation was supported by varied political coalitions, albeit for different reasons.

At the same time, other social innovations among the case studies in the WILCO project were limited in their development because others downplayed the contested nature of their work or because they were bogged down by local political conflicts. It was sometimes impossible to distinguish successful from failed cases because there was no consensus on what their goals should have been. In the case of neighbourhood revitalization innovation in Zagreb, for example, a lack of coordination between local government offices and local city companies affected the visibility of the innovation in a negative manner (Bezovan et al. 2014b). Public strategies or social marketing were consequently not on the agenda due to political conflicts, including an unstable political situation, resignation of a mayor and local elections. Another example of political conflicts disabling social innovations was found in the city of Varaždin (Bezovan et al. 2013).

The role and recognition of civil society in the development of social innovation has strengthened over time. However, as argued in the research, political turbulence and changes to power structures hindered the development of more systematic cooperation from being established. There are examples of cities and local contexts, such as Lille, in which the local political arena for social innovation remains weakened by attention paid to a limited number of other priorities due to economic crisis and budget cuts (Fraisse and Bia Zafinikamia 2013). There are also cities, such as Malmö, in which local political disagreements hindered the implementation of particular innovations (see Chap. 6 in this book). Even though there was political consensus about the need for new solutions in local welfare in general and the promotion of social innovation as a concept in particular, different stakeholders and coalitions disagreed regarding the methods and instruments to be implemented, affecting the emergence and development of social innovations.

If the practice of social innovations has more to do with changes in social relations than products or processes, they are necessarily also conflict-ridden and political by nature. Those who claim to study the phenomenon with any seriousness must at least incorporate this much. Resistance and opposition, risks and dangers, as well as negative effects and misuse need to be taken seriously, regardless of the normative good of social innovations (Borins 2001).

Such conflicts are rarely discussed in the current mainstream of social innovation literature. Ironically, in its denial of politics, social innovation literature is profoundly political. Being aware of the local context and by implication of the local politics was one of the hallmarks of the WILCO project's approach. 


\subsection{Inflated Expectations of Diffusion}

One of the main objectives of the WILCO project was expressed as identifying the "key factors for diffusion and upgrading of (social) innovations" (Evers et al. 2014, p. 9). At least three different positions on the possibility and desirability of diffusion can be identified (see Lewis 2007; Segnestam Larsson 2013), two of which explicitly challenge the assumption that social innovations easily can be diffused to other cities and local contexts. The first is the view that suggests that the transfer of best practices among different kinds of local contexts and organisations is easy and desirable (Herman and Renz 1999; Roberts et al. 2005; Shoham et al. 2006).

This view has been disproven already (see the previous chapter), and the WILCO evidence only serves to underline this. Diffusion did not always occur where it was sensible, sometimes simply because of economic reasons. One example was the case of economic circumstances in relation to nonprofit housing in Varaždin (Bezovan et al. 2014b). Even though one of the analytical results of the case study revealed that this innovation showed the capacity to become a model for other cities with sufficient diffusion capacity, the economic crisis that influenced the fiscal capacities of cities across Croatia at the time of research hindered diffusion even within the city of Varaždin. Economic circumstances like too much dependence on public funding for stability were also mentioned as a limiting factor, for example, in the case study of neighbourhood revitalization in Geneva (Kapko and Cattacin 2014).

In other cases, diffusion did not take place because innovations could not match the relevant bureaucratic criteria to be considered worthy of partnership (cf. Borins 2001). Since its creation, a housing association in Nantes had regularly been invited by public actors to participate in activities aiming to create strategic priorities regarding care for elderly people (Coqblin and Fraisse 2014). However, public actors regarded the association as an experimental project still in the making, not as a regular partner in the development of social policies. Moreover, the case of housing revitalization in Geneva shows that what other parties considered a lack of relevant assessment also prevented diffusion (Kapko and Cattacin 2014).

Such limitations to the diffusion of social innovations are acknowledged in the more critical strand of social innovation research (Rogers and Shoemaker 1971; Loch and Huberman 1999; Damanpour and Gopalakrishnan 2001), in which two more critical views can be distinguished. One of these could be labelled the "adaptive" view. Researchers and practitioners who support this view argue that although social innovations from one context may have relevance for another context, they cannot be applied in a simple or straightforward manner (Åberg 2008; Maier and Meyer 2011; Sahlin and Wedlin 2008). Instead, the desired social innovation has to be adapted or translated into the local context.

Indeed, we found that - given this process of adaptation-a number of innovations went through a process of translation and localization. Some of these innovations represented approaches that, even though they were new in the context where they appeared, represented international trends, having emerged in many sites and cities across Europe. This concerned three types of innovations in particu- 
lar. The first type of social innovations was social enterprises working in the field of occupational and social integration as so-called "work integration enterprises", such as the employment social innovation of Filur in Stockholm (Nordfeldt and Carrigan 2014a). Additional examples of this type of social innovations that appeared in many sites and cities across Europe were found in Barcelona, Plock and Varaždin (Montagut et al. 2014; Siemieńska et al. 2014; Bezovan et al. 2014c). The second type of social innovations representing international trends was participative and community-oriented forms of revitalising housing estates and urban neighbourhoods (e.g. Bezovan et al. 2014b; Nordfeldt and Carrigan 2014b; Kapko and Cattacin 2014). Finally, the third type of social innovations to be mentioned here was family support services and centres of various kinds. Despite differences, their common innovative core was to direct offers of support to the whole family system instead of focusing solely on childcare services. This type of social innovations was common in contexts as different as Italy, England or Germany (Costa and Sabatinelli 2014; Brookes et al. 2014; Ewert and Evers 2014). The combination of the three types of social innovation, including similarities and differences across sites and cities, suggests that diffusion did take place but with local translations and adaptations.

Yet, there is a third and more critical position towards the import of social innovations, suggesting that the process of mainstreaming leads to a standardization of solutions and the trimming of more critical elements of the original innovation (Boyd 2004; Galston 2005; Jensen and Miszlivetz 2006). This is not something the WILCO project examined systematically, and it is up to future research to apply this more critical position to the possibility and desirability of diffusion.

On the basis of the existing evidence, we can conclude that there is no direct relationship between the potential value of an innovation and its opportunities to be diffused. The picture of a swift and easy transfer is therefore misleading.

\subsection{Conclusion}

In order to provide some counterweight against the inevitable parade of successful innovations that comes out of such a project as WILCO, we adopted a more critical perspective on social innovation research. As this chapter has shown, many perspectives on social innovations have explicit or hidden normative assumptions that obscure the dark side of the phenomenon: the failures, the conflicts and the oppression of universalistic approaches.

As argued in the previous sections, attention for detail and a diverse group can go some way in preventing such assumptions from stifling the debate. In the end, one should always have a few critical questions at hand. Who benefits from the introduction of social innovations? Who loses? Did anything get worse? Common sense also helps. In the context of welfare, many of the problems are what policy science calls wicked problems, such as poverty, addictions and homelessness. These do not have easy or ultimate solutions. Eldorado is not around the corner. 
Academically, the added value of social innovation is less in its conceptual contribution - this is very limited - than in its potential ability to bind several disciplinary traditions together. It is a pity, then, that much of the social innovation research has been relatively weak in incorporating the more mature conceptual and theoretical insights from these traditions. In another function, as a concept bridging theory and practice (in the words of Jenson and Harrison, a "quasi-concept"), it has been more effective (European Commission 2013, p. 16). However, on both scores, its potential can only be fully realised when there is more honesty about covert assumptions and the dark side of social innovations.

Open Access This chapter is distributed under the terms of the Creative Commons AttributionNonCommercial 4.0 International License (http://creativecommons.org/licenses/by-nc/4.0/), which permits any noncommercial use, duplication, adaptation, distribution and reproduction in any medium or format, as long as you give appropriate credit to the original author(s) and the source, a link is provided to the Creative Commons license and any changes made are indicated.

The images or other third party material in this chapter are included in the work's Creative Commons license, unless indicated otherwise in the credit line; if such material is not included in the work's Creative Commons license and the respective action is not permitted by statutory regulation, users will need to obtain permission from the license holder to duplicate, adapt or reproduce the material.

\section{References}

Åberg, P. (2008). Translating popular education: Civil society cooperation between Sweden and Estonia (Diss.) Department of Political Science, Stockholm University.

Bezovan, G., Matančević, J., \& Baturina, D. (2013). City Report: Varazdin. WILCO project, published on www.wilcoproject.eu.

Bezovan, G., Matančević, J., \& Baturina, D. (2014a). Social mentoring project for employment of disadvantaged and marginalised groups. In A. Evers, B. Ewert, \& T. Brandsen (Eds.), Social innovations for social cohesion. Transnational patterns and approaches from 20 European cities (pp. 33-36). www.wilcoproject.eu. WILCO project.

Bezovan, G., Matančević, J., \& Baturina, D. (2014b). Public works Varaždin. In A. Evers, B. Ewert, \& T. Brandsen (Eds.), Social innovations for social cohesion. Transnational patterns and approaches from 20 European cities (pp. 62-64). www.wilcoproject.eu: WILCO project.

Bezovan, G., Matančević, J., \& Baturina, D. (2014c). Non-profit housing organisation. In A. Evers, B Ewert, \& T. Brandsen (Eds.), Social innovations for social cohesion. Transnational patterns and approaches from 20 European cities (pp. 49-52). www.wilcoproject.eu: WILCO project.

Borins, S. (2001). The challenge of innovating in government. Washington, DC: IBM Centre for the Business of Government.

Boyd, R. (2004). Uncivil society. The perils of pluralism and the making of modern liberalism. Oxford: Lexington Books.

Brookes, N., Kendall, J., \& Mitton, L. (2014). Lone parent support. In A. Evers, B. Ewert, \& T. Brandsen (Eds.), Social innovations for social cohesion. Transnational patterns and approaches from 20 European cities (pp. 389-390). www.wilcoproject.eu: WILCO project.

Bureau of European Policy Advisers (BEPA). (2010). Empowering people, driving change. Social Innovation in The European Union. http://ec.europa. eu/bepa/pdf/publications_pdf/social_innovation.pdf.

Carrigan, A., \& Nordfeldt, M. (2014). Bimbo chiama bimbo - Child calls child. In A. Evers, B. Ewert, \& T. Brandsen (Eds.), Social innovations for social cohesion. Transnational patterns and approaches from 20 European cities (pp. 335-346). 
Coqblin, A., \& Fraisse, A. (2014). Le temps pour toit-Time for roof. In A. Evers, B. Ewert, \& T. Brandsen, T. (Eds.), Social innovations for social cohesion. Transnational patterns and approaches from 20 European cities (pp. 93-95). www.wilcoproject.eu: WILCO project.

Costa, G., \& Sabatinelli, S. (2014). Malmö. In A. Evers, B. Ewert, \& T. Brandsen, T. (Eds.), Social innovations for social cohesion. Transnational patterns and approaches from 20 European cities (pp. 164-167). www.wilcoproject.eu: WILCO project.

Damanpour, F., \& Gopalakrishnan, S. (2001). The dynamics of the adoption of product and process innovations in organizations. Journal of Management Studies, 38(1), 45-65.

Drejer, I. (2004). Identifying innovation in surveys of services: A schumpeterian perspective. Research Policy, 33(3), 551-562.

Eshima, Y., Katayama, T., \& Ohno, T. (2001). Public management innovation in Japan: Its characteristics and challenges. International Review of Administrative Sciences, 67(4), 699-714.

European Commission. (2013). Social innovation research in Europe: Approaches, trends and future directions. Brussels: DG Research/WILCO Project.

Evers, A., Ewert, B., \& Brandsen, T. (Eds.). (2014). Social innovations for social cohesion. Transnational patterns and approaches from 20 European cities. www.wilcoproject.eu: WILCO project.

Feller, I. (1981). Public sector innovations as conspicuous production. Policy Analysis, 7(1), 1-20.

Fledderus, J., Broersma, F., \& Brandsen, T. (2014). Nijmegen. In A. Evers, B. Ewert, \& T. Brandsen, T. (Eds.), Social innovations for social cohesion. Transnational patterns and approaches from 20 European cities (pp. 223-242). www.wilcoproject.eu: WILCO project.

Fraisse, L., \& Bia Zafinikamia, M.-L. (2013) City report: Lille. WILCO project, published on www.wilcoproject.eu.

Galston, W. A. (2005). The practice of liberal pluralism. Cambridge: Cambridge University Press.

Garcia, R., \& Calantone, R. (2002). A critical look at techological innovation typology and innovativeness terminology: A literature review. Journal of Product Innovation Management, $19,110-132$.

Harris, M., \& Aldbury, D. (2009). The innovation imperative. London: NESTA.

Hendrickson, M. A. (2014). Pamplona. In A. Evers, B. Ewert, \& T. Brandsen (Eds.), Social innovations for social cohesion. Transnational patterns and approaches from 20 European cities (pp. 303-316). www.wilcoproject.eu: WILCO project.

Herman, R. D., \& Renz, D. O. (1999). Theses on nonprofit organizational effectiveness. Nonprofit and Voluntary Sector Quarterly, 28(2), 107-126.

Hill, M., \& Hupe, P. (2009). Implementing public policy. London: Sage.

Jensen, J., \& Miszlivetz, F. (2006). Global civil society: From dissident discourse to World Bank Parlance. In P. Wagner (Ed.), The languages of civil society (pp. 177-205). Oxford: Berghahn Books.

Joerges, B., \& Nowotny, H. (Eds.). (2003). Social studies of science and technology: Looking back, ahead. Boston: Kluwer Academic Publishers.

Kapko, N., \& Cattacin, S. (2014). The unit for temporary housing. In A. Evers, B. Ewert, \& T. Brandsen (Eds.), Social innovations for social cohesion. Transnational patterns and approaches from 20 European cities (pp. 375-380). www.wilcoproject.eu: WILCO project.

Lewis, D. (2007). The management of non-governmental development organisations (2nd ed.). London: Routledge.

Loch, C., \& Huberman, B. (1999). A punctuated equilibirum model of technology diffusion. Management Science, 45(2), 160-177.

Maier, F., \& Meyer, M. (2011). Managerialism and beyond: Discourses of civil society organization and their governance implications. Voluntas: International Journal of Voluntary and Nonprofit Organizations, 22(4), 1-26.

Meeuwisse, A. (2008). Organizational innovation in the Swedish Welfare State. Critical Social Policy, 28(2), 187-205.

Membretti, A. (2007). Building citizenship as an innovative service. European Urban and Regional Studies, 14(3), 252-263.

Miller, P., \& Rose, N. (2008). Governing the present. Administering economic, social, and personal life. Cambridge: Polity Press. 
Montagut, T., Marta Llobet, G. V., \& Riutort, S. (2014). Citizens' agreement for an inclusive Barcelona. In A. Evers, B. Ewert, \& T. Brandsen (Eds.), Social innovations for social cohesion. Transnational patterns and approaches from 20 European cities (pp. 294-296). www. wilcoproject.eu: WILCO project.

Moulaert, F. (2010). Social innovation and community development. Concepts, theories and challenges. In F. Moulaert, F. Martinelli, E. Swygedouw, \& S. González (Eds.), Can neigbourhoods save the city? (pp. 4-16). London: Routledge.

Mulgan, G. (2006). The process of social innovation. Innovations, 1(2), 145-162.

Murray, R., Grice, J., \& Mulgan, G. (2010). The open book of social innovation. London: NESTA.

Nordfeldt, M., \& Carrigan, A. (2014a). The Filur project. In A. Evers, B. Ewert, \& T. Brandsen (Eds.), Social innovations for social cohesion. Transnational patterns and approaches from 20 European cities (pp. 321-324). www.wilcoproject.eu: WILCO project.

Nordfeldt, M., \& Carrigan, A. (2014b). Miljardprogrammet (The Billion Programme). In A. Evers, B. Ewert, \& T. Brandsen (Eds.), Social innovations for social cohesion. Transnational patterns and approaches from 20 European cities (pp. 328-333). www.wilcoproject.eu: WILCO project.

Normann, R. (2007). Service management. Strategy and leadership in service business. Chichester: Wiley.

Osborne, S. (1998). Naming the beast: Defining and classifying service innovations in social policy. Human Relations, 51(9), 1133-1154.

Osborne, S., \& Brown, L. (2011). Innovation, public policy and public services delivery in the UK: The word that would be king? Public Administration, 89(4), 1335-1350.

Pestoff, V., \& Brandsen, T. (2006). Co-production, the third sector, and the delivery of public services. Public Management Review, 8(4), 493-502.

Pettigrew, A. (1973). Politics of organizational decision making. London: Tavistock.

Phillis, J. (2008). Rediscovering social innovation. Stanford Social Innovation Review, 6(4), 36-43.

Roberts, S., Jones, J. III, \& Fröhling, O. (2005). NGOs and the globalization of Managerialism: A research framework. World Development Report, 33(11), 1845-1864.

Rogers, E., \& Shoemaker, F. (1971). Communication of innovation. New York: The Free Press.

Sahlin, K., \& Wedlin, L. (2008). Circulating ideas: Imitation, translation and editing. In R. Greenwood, C. Oliver, K. Sahlin, \& R. Suddaby (Eds.), The SAGE handbook of organizational institutionalism (pp. 218-242). London: Sage.

Scott, J. C. (1998). Seeing like a state: How certain schemes to improve the human condition have failed. Yale: Yale University Press.

Segnestam Larsson, O. (2013). Convergence in ideas, divergence in actions: Organizational hypocrisy in nonprofit organizations. Administrative Theory \& Praxis, 35(2).

Shoham, A., Ruvio, A., Vigoda-Gadot, E., \& Schwabsky, N. (2006). Market orientations in the nonprofit and voluntary sector: A meta-analysis of their relationships with organizational performance. Nonprofit and Voluntary Sector Quarterly, 35(3), 453-476.

Siemieńska, R., Domaradzka, A., \& Matysiak, I. (2014). Foundation "Grant Fund for Plock". In A. Evers, B. Ewert, \& T. Brandsen (Eds.), Social innovations for social cohesion. Transnational patterns and approaches from 20 European cities (pp. 278-283). www.wilcoproject.eu: WILCO project.

Sundbo, J. (1997). Management of innovation in services. Service Industry Journal, 17(3), 432 455.

Tether, B. (2003). The sources and aims of innovation in services. Economics of Innovation and New Technology, 12(6), 841-855. 